Rokkones, K. (2017). «Den tredje vei»: En studie av elevers opplevelse av å være lærekandidat.

Scandinavian Journal of Vocations in development

http://dx.doi.org/10.7577/sjvd.2582

Fagfellevurdert artikkel

(Peer reviewed article)

\title{
«Den tredje vei»: En studie av elevers opplevelse av å vare lærekandidat.
}

Forfatter:

Klara Rokkones

Institutt for lærerutdanning,

Norges teknisk-naturvitenskapelige universitet (NTNU)

Klara.rokkones@ntnu.no

Nøkkelord: læring, sosial kompetanse, grunnkompetanse, frafall, lærekandidat, kontaktlærer, klasseledelse, kvalitativ forskning, fenomenologiske intervju. 


\section{Sammendrag}

Denne artikkelen er basert på en kvalitativ undersøkelse som tar utgangspunkt i erfaringer og opplevelser elever/lærekandidater på restaurant- og matfag og helse- og oppvekstfag har fra et alternativt opplæringsløp. De har alle vært knyttet til et tilrettelagt tilbud, «Den tredje vei», som er bygget opp omkring praksis, og som kjennetegnes med stor fleksibilitet. Problemstillingen jeg forfølger i teksten, er følgende: Hvordan kan skole og bedrift samarbeide og tilpasse opplaringen for elever med behov for en alternativ vei til grunnkompetanse?

I første del av artikkelen beskrives tilbudet «Den tredje vei» og knyttes til sentrale styringsdokumenter, teori og forskning.

I artikkelens andre del presenterer jeg metode og datainnsamling, basert på intervjuer.

Til slutt drøfter og oppsummeres funnene i studien som omfatter elevenes/lærekandidatenes erfaringer og opplevelser. Jeg peker på hvordan studien kan være et bidrag til å forstå behovet for en bedre tilpasset opplæring for elever med ulike utfordringer, og hvordan dette kan organiseres i skole og bedrift. 


\section{English summary:}

\section{"The third way": A study of pupils' perceptions of being a trainee}

This article is based on a qualitative study of the experiences and perceptions trainees in the upper secondary school subjects of restaurant and food processing and health and social care have of an alternative education pathway. They have all been connected to a specially designed programme - "The third way" - which is based on practical training and characterised by a great amount of flexibility. The research question for the study is: How can schools and companies cooperate and adapt the teaching for pupils needing an alternative way to achieve basic competence?

The first section of the article describes the "The third way" programme and connects it to important governance documents, theory and research.

In the second section of the article I present my methodology, the interviewes and datacollection strategies.

Finally, I discuss and summarise the findings in the study which relate to the experiences and perceptions of the pupils/ trainees. I point out how the study may contribute to understanding the need for teaching/training that is better adapted to pupils with various challenges, and how this can be organised in schools and companies.

Keywords: Learning, social competence, basic competence, non-completion, trainee, homeroom teacher, classroom management, qualitative research, phenomenological interview 


\section{Innledning}

En bedre tilpasset opplæring bør vektlegges for alle elever i videregående opplæring for at flest mulig skal kunne gjennomføre og oppnå en grunnkompetanse. Mål om å bli lærekandidat ${ }^{i}$ kan være en slik tilpasning. Dette er målet for en gruppe elever som følges i prosjektet «Den tredje vei» som beskrives i denne artikkelen. Markussen m. fl. (Markussen, Lødding, Sandberg \& Vibe, 2006) mener at økt bruk av lærekandidatordningen eller andre alternative utdanningsløp med grunnkompetanse som siktemål, imøtekommer behovet for en økt vekt på tilpasset opplæring. Et annet alternativt utdanningsløp er praksisbrev (Markussen et al., 2006; Markussen, 2009; Høst, 2011, 2013). Svake kunnskaper og ferdigheter er den viktigste forklaringen på at elevene ikke består eller slutter i videregående skole (Markussen et al., 2006; Markussen, Frøseth, Hovedhaugen, Wigum, 2012). Forfatterne mener derfor at det er avgjørende å ta variasjon i kunnskaper og ferdigheter på alvor, og å gjennomføre en opplæring som tar hensyn til dette. Det må tas utgangspunkt i de elevene man har, og oppgaven er å gi flest mulig grunnkompetanse som gjør at de består videregående opplæring.

I videregående opplæring kan elevene fullføre opplæringen med grunnkompetanse i studieforberedende - og yrkesfaglige utdanningsprogram. I opplæringslovens $§ 3-3$ (Opplæringslova, 1998, § 3-3) beskrives grunnkompetanse som opplæring som ikke fører til full studie- eller yrkeskompetanse. Opplæring mot grunnkompetanse i lærebedrift reguleres gjennom lærekandidatordningen. Denne ordningen avgrenser ikke opplæringens lengde og innhold, men er et individuelt tilpasset opplæringsløp med en kompetanseprøve som er mindre omfattende enn ordinær fag- og svenneprøve (Opplæringsloven, § 4-1).

Frafall i videregående skole er et stadig debattert tema innen norsk skolepolitikk. Frafall er ikke noe nytt problem, jfr. Hernes i rapporten: Gull av gråstein. Tiltak for å redusere frafall $i$ videregående opplcering (Hernes, 2010). Når frafall automatisk omtales som et problem, knyttes dette til at frafall reduserer mulighetene til jobb og øker risikoen for uføretrygd og et voksenliv utenfor arbeidslivet. Frafall øker sannsynlighet for dårligere levekår og helse gjennom hele livet (Hernes, 2010, s. 7). Frafallet er dokumentert betydelig større på yrkesfag enn på studieforberedende (Statistisk sentralbyrå (SSB), 2013).

Utvær (Utvær, 2013) oppsummerer sin forskning av frafall i videregående skole frafallsforskning med å påpeke at elevenes indre aspirasjoner i læringssituasjonen er viktig. 
Indre aspirasjoner handler om hva eleven verdsetter og streber for å oppnå. Hun beskriver videre at mening i programfagene er mer avgjørende for om elevene fortsetter i et påbegynt utdanningsløp enn mening i fellesfagene. Utvær sier at mye kan gjøres i skolen for å gjøre opplæringen mer meningsfull, det gjelder både i programfagene og fellesfagene. Læreren fremheves som svært viktig. Videre at interessen for programfagene og gode praksisopplevelser er avgjørende for at elever skal fortsette i utdanningsløpet. Gode relasjoner til sentrale voksne i skolen er i tillegg av stor betydning, kanskje spesielt hvis elevene har mange dårlige skoleerfaringer fra grunnskolen. Noen elever er spesielt sårbare og trenger svært mye støtte for å stå løpet ut. Dette er i samsvar med funn gjort i studier av «Den tredje vei» (Rokkones \& Saur, 2013, 2014).

Markussen mfl. (Markussen et al., 2006; Markussen, Lødding, Holen, 2012) viser til at det er en tett sammenheng mellom sosial bakgrunn, karakterer ved avslutning av ungdomstrinnet og gjennomføring i videregående skole. Bare halvparten av de som i dag starter på en yrkesfaglig utdanning i videregående opplæring, gjennomfører i løpet av fire år. Prosjektet «Den tredje vei» er et opplæringsløp tilpasset den enkelte elev i en lokal kontekst med det målet at vedkommende skal få grunnkompetanse gjennom lærekandidatordningen. Det er et konkret tilbud for å redusere frafallet. Denne artikkelen tar utgangspunkt i følgende problemstilling: Hvordan kan skole og bedrift samarbeide og tilpasse opplaringen for elever med behov for en alternativ vei til grunnkompetanse?

I teksten som følger vil jeg gi en beskrivelse av prosjektet «Den tredje vei». Videre følger en presentasjon av mitt teoretiske rammeverk samt sentrale styringsdokumenter. Deretter en metodedel som presenterer intervju med lærekandidatene. Til slutt kommer analyse og drøfting, samt en oppsummering.

\section{«en tredje vei»}

«Den tredje vei» er et opplæringsløp med mål om at elevene skal oppnå grunnkompetanse gjennom lærekandidatordningen. Opplæringen inkluderer både faglige og sosiale mål i et langsiktig løp som kvalifiserer eleven for en jobb (Utdanningsdirektoratet, 2006). Alle mål tar utgangspunkt i elevens forutsetninger og interesser. Fleksibilitet vektlegges gjennom hele opplæringsløpet. Inntak av elever skjer gjennom hele året, dette anses som en av styrkene med 
prosjektet. Elevene rekrutteres på bakgrunn av ovennevnte kriterier. Det betyr at noen er klar ved skolestart på bakgrunn av tidligere erfaringer, mens andre kommer til etter hvert på bakgrunn av de erfaringene som gjøres i første skoleår. «Den tredje vei» er ikke et søkbart tilbud for elever fra ungdomsskolen, elevene søker inntak på ordinære kurs. Dette gjør at skolen kan være mer fleksibel og ha mer styring med rekrutteringen fra de ordinære klassene både tidlig høst og videre ut i skoleåret.

Elevene i prosjektet deltar i et kombinert opplæringsløp i skole og bedrifter med mål om å bli lærekandidater. De er omfattet av samme lovverk som andre elever/lærekandidater i videregående skole/opplæring. Som elev/lærekandidat har de en individuell opplæringsplan (IOP), som dekker deler av læreplanmålene som fører frem til kompetansebevis.

Elevene som deltar i prosjektet, har tidligere hatt høyt skolefravær. Andre fellestrekk ved gruppa er kommunikasjonsproblemer, konsentrasjonsproblemer, angst og depresjon. Den største utfordringen synes å være tilbaketrekning og kommunikasjonsproblemer. Prosjektet har en strategisk sammensetning for å inkludere disse problemene. Flere har diagnoser som har gjort samarbeid med støttefunksjoner og etater utenfor skolen nødvendig.

Opplæringsloven og læreplaner (Opplæringslova, 1998; Utdanningsdirektoratet, 2006a, b) innenfor utdanningsprogrammene på restaurant- og matfag (RM) og helse- og oppvekstfag (HO) er utgangspunktet for elevenes opplæring. De gir også sentrale føringer for skole og lærebedrift om å gi alle elever/lærlinger/lærekandidater like muligheter for å utvikle evner og talent individuelt og i samarbeid med andre.

Prosjektet startet i skoleåret 2012/13 og ble videreført i 2013/14 og 2014/15. Antallet elever i prosjektet varierte mellom 8 og 11, øvre grense har vært 12 elever. Felles hovedmål for alle er å tegne lærekandidatkontrakt. På skolen har elevene fire dager praksis og en dag med kroppsøving, norsk og programfag, etter hvert kombineres dette med praksis i bedrift. Kontaktlærer og prosjektleder har fulgt «Den tredje vei» siden oppstart høst 2012, og er der fortsatt våren 2015 i prosjektets tredje år. Sammen utgjør de prosjektets kontinuitet og forutsigbarhet for elevene. Prosjektleder koordinerer det tverretatlige samarbeidet ut fra behovet hos den enkelte elev, og har ansvaret for dialogen med bedriftene, skoleeier (fylkeskommunen), NAV og andre instanser utenfor skolen i forhold til lærekandidatkontraktene. Det er stor fleksibilitet når det gjelder å kunne ta inn nye elever. 
Prosjektleder arbeider fortløpende med å få på plass flere lærekandidatkontrakter. Skolen har fått god støtte fra fagenheten for videregående opplæring, som også har bidratt økonomisk for videreføring av tilbudet.

\section{Teoretisk rammeverk og politiske dokumenter}

Elevene som etter hvert skifter status til lærekandidater i «Den tredje vei» er ungdommer som har fått et tilbud om en alternativ vei frem mot grunnkompetanse. For skolen er de nasjonale læreplanene et av de viktigste styringsinstrumentene. Alternative veier frem mot en grunnkompetanse styres og reguleres av nasjonale føringer. Tilpasset opplæring er et gjennomgående prinsipp i hele opplæringen og er nedfelt i Opplæringsloven $\S 1-2$. I tillegg er det lagt stor vekt på fysiske og det psykososiale miljøet for elevene $\mathrm{i}$ «Den tredje vei» (Opplæringsloven, 1998, § 9a 1-4).

\section{Klasseledelse og kontaktlærer}

Klasseledelse og kontaktlæreres rolle (Rokkones, 2014) er sentral i prosjektet. En positiv relasjon mellom lærer og elev er hjørnesteinen i god klasseledelse (Marzano, 2007; Nordahl, 2012; Utdanningsdirektoratet, 2012). Ogden (Ogden, 2012) beskriver klasseledelse som lærerens kompetanse i å holde orden og skape produktiv arbeidsro, fremme og skjerme undervisning og læringsaktiviteter i samarbeid med elevene. I dette prosjektet har skolen satset på at det er samme kontaktlærer som har fulgt «Den tredje vei» siden oppstart og frem til i dag. Det betyr mer forutsigbart for elevene og lærerne som jobber i prosjektet. I «Den tredje vei» stilles det store krav til kontaktlærer for å ivareta elevene siden de tidligere har hatt dårlige erfaringer med skolen. Lærerens kompetanse og evne til å utvikle ulike relasjoner er viktige for elevenes læring og utvikling (Nordahl, 2002). Kontaktlærers evne til å vektlegge utvikling av læringsmiljøet i klassen er sentralt, dette henger nøye sammen med utøvelse av god klasseledelse. For yrkesfag omfatter læringsmiljø også et arbeidsfellesskap som etableres gjennom praktisk arbeid i verksted, i tillegg til det som etableres i klasserommet. I rollen som kontaktlærer og i utøvelsen av klasseledelse blir det sentralt å bry seg om alle elevene og vise interesse for den enkelte. For å kunne handle proaktivt, må læreren ha god kompetanse til å analysere og forstå læringsfellesskapet i klasserommet 
(Ogden, 2004). Elevene må oppleve at kontaktlæreren har god struktur i undervisningen, er støttende og har høye forventninger til hvordan de kan utvikle seg både faglig og sosialt.

\section{Sosial kompetanse}

Utvikling av sosial kompetanse er et sentralt mål for hele grunnopplæringen og gjelder alle elever. En viktig del av grunnleggende ferdigheter handler om utvikling av elevenes sosiale kompetanse og understrekes i Strategi for ungdomstrinnet (Kunnskapsdepartementet, 2012), stortingsmelding 20, På rett vei, kvalitet og mangfold i fellesskolen (Kunnskapsdepartementet, 2013). Læring av sosial kompetanse uttrykkes som skolens ansvar både i Opplæringslovens $\S$ 1.1 (Opplæringslova, 1998, § 1-1) og Kunnskapsløftet (Utdanningsdirektoratet, 2006).

Skolens krav om og forventninger til sosial kompetanse kan skape problemer for barn og unge som hjemme er vant til andre former for sosial kompetanse (Nordahl, 2010). Opplæringen skal legge til rette for at elevene utvikler kunnskaper, ferdigheter og holdninger som gjør dem i stand til å mestre livet og delta i sosiale fellesskap med andre (Ogden, 2009). I opplæringen i skolen møter elevene et slikt sosialt fellesskap av jevnaldrende, og her skal de lære seg sosiale ferdigheter. For elevene på yrkesfag vil også det sosiale fellesskapet omfatte voksne når de skal ut som lærekandidater/lærlinger i bedrift/virksomhet. Utvikling av sosiale kompetanse er sentralt $\mathrm{i}$ «Den tredje vei». Sosial kompetanse er nødvendig for å mestre ulike sosiale miljøer, som gjør det mulig å etablere og vedlikeholde sosiale relasjoner, og som bidrar til at trivsel økes og utvikling fremmes (Garbarino, 1985).

\section{Elevenes læring}

Læring kan defineres som forskjellen mellom det man kunne fra før, og det man skal kunne eller kan nå, og som det har vært nødvendig og tilegne seg. Læringen kan være endring av ferdigheter, i adferd, i holdninger og i følelser, og er i bunn og grunn styrt av liv og nødvendighet. Læring har alltid utgangspunkt i en sosial sammenheng, for eksempel samhandling mellom elever og lærere. I arbeidslivet vil elevene oppleve andre rammer og forventninger enn i skolen. De vil erfare at ikke alt de lærte i skolen er relevant for de utfordringer de møter ute på arbeidsplassen. Illeris (Illeris, 2012) beskriver de ulike læringsarenaene vi møter som læringsrom. Han beskriver læringsrom som tar utgangspunkt i hverdagslivet, skole- og utdanningssystemet, interessebetonte læringsrom, nettbasert læring og det frivillige. Det er viktig at vi som lærere er bevisste på at læring skjer på ulike arenaer. 
Det kan gjøre oss i bedre stand til å tilpasse opplæringen for den enkelte elev. For elevene/lærekandidatene kan det praktiske og det de lærer ute i arbeidslivet, oppleves som mer brukbart og relevant enn skolekunnskapene. Etter hvert vil de kanskje også oppdage at denne kunnskapen vil bli mer forståelig og nyttig hvis den kobles til teori. I et samfunn med rask utvikling er det viktig at vi legger til rette for at det etableres læringsmessige sammenhenger på tvers av læringsrommene (Illeris, 2012).

For å vurdere læringen brukes ofte tester og øvinger, gjerne i konkurranse med medelever, om hvem får best karakter. Ofte må elevene demonstrere sin kunnskap utenfor en kontekst og der samarbeid ikke eksisterer eller oppfattes som ulovlig. Testene er i stor grad individuelle og legger i liten grad opp til samarbeid. Tradisjonell undervisning og opplæring oppfattes av mange elever som irrelevant, kjedelig og vanskelig (Lave \& Wenger, 2003). Manglende relevans og ikke-eksisterende kontekst i flere fag kan ha medført at elevene har droppet ut av de skolene de har vært en del av (Lave \& Wenger, 2003, Wenger, 2013). Wenger (2013) fokuserer på læring som sosial deltakelse som omfatter å være en del av sosiale fellesskap praksiser - og å konstruere identiteter i relasjon til disse fellesskapene. Å være med i et slikt fellesskap er en type handling og en måte å få tilhørighet på. En slik handling former ikke bare hva vi gjør, men også hvem vi er, og hvordan vi fortolker hva vi gjør. En sosial teori om læring må derfor integrere flere komponenter for å karakterisere sosial deltakelse som en prosess som omfatter læring og innsikt.

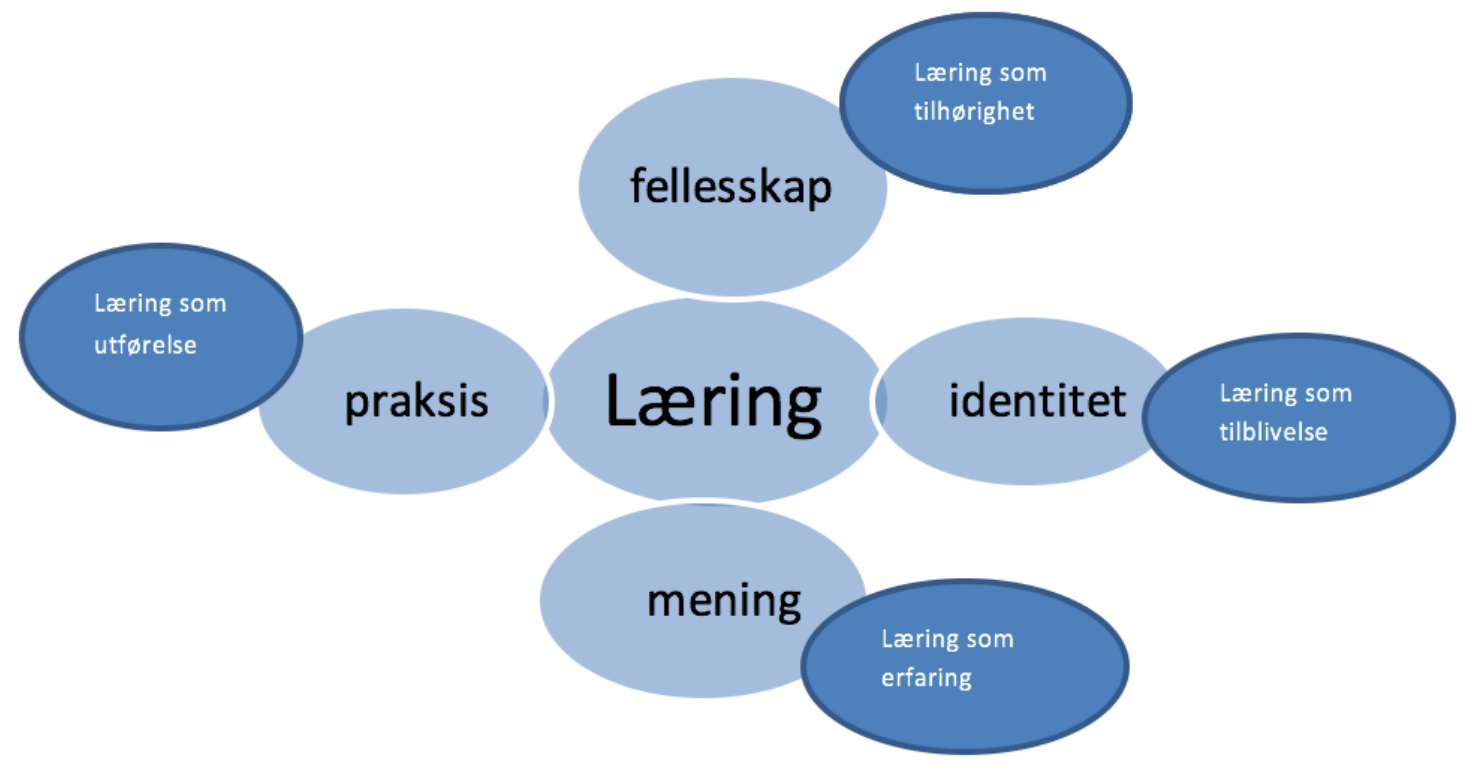

Figur 1. Læring som sosial deltagelse (Wenger, 2013) 
Figuren viser hvordan ulike komponenter påvirker læring, og den favner godt intensjonen i «Den tredje vei» der læring er organisert rundt fellesskap, praksis, relevans- mening, mulighet for identitetsutvikling, opplevelse av tilhørighet. Elevene får prøve ut og deler erfaring med hverandre. Videre rommer figuren tilpasset opplæring og varierte arbeidsmåter som skal sikre at det fysiske og psykososiale arbeids- og læringsmiljøet fremmer læring i tråd med læringsplakaten (Utdanningsdirektoratet 2006c; Kunnskapsløftet, 2006).

\section{Metode}

\section{Datainnsamling}

Sentralt er intervju med fire elever/lærekandidater som har vært en del av «Den tredje vei» siden oppstart i 2012. Utvalget og forespørselen til elevene/lærekandidatene er gjort i et samarbeid med prosjektleder. Intervjuene er gjennomført individuelt i den enkeltes lærebedrift med utgangspunkt i samme tema, og spørsmålene var planlagte og formelle (Postholm, 2010). Intervjuene er basert på fenomenologisk teori og metode med bakgrunn i at jeg ville finne essensen i eller fellesnevneren for opplevelser knyttet til en bestemt erfaring (Moustakas, 1994), i dette tilfellet erfaringer alle elevene/lærekandidatene har gjort i sin opplæring i skole og bedrift. De fem (fire) lærekandidater representerer både RM og HO. En meldte frafall på grunn av sykdom. Antallet intervjudeltakere ble valgt på grunnlag av Dukes (Duke, 1984) teori om at tre til ti personer bør være deltakere i en fenomenologisk studie. For å finne essensen eller kjernen i opplevelsen er det en forutsetning at deltakerne blir spurt om de samme temaene. Følgende spørsmål ble stilt til alle elevene/lærekandidatene: Hvilke erfaringer har du med skoletilbudet generelt? Hvilke erfaringer har du med «Den tredje vei»? Er det spesielle erfaringer - opplevelser du har fra skoleåret du vil trekke frem? Hvordan opplevde du det sosiale fellesskapet i gruppa? Hadde du gjort et yrkesvalg før du kom til gruppa? Hvem har påvirket ditt valg av fag - programområde? Hvordan påvirket innholdet og organiseringen av undervisningen ditt valg av programområde? Hvordan opplevde du møtet med praksis ute i bedrift? Hvordan ble du møtt? Hvordan fungerte oppfølgingen fra skolen? Hva liker du spesielt godt med de arbeidsoppgavene du jobber med i bedriften? Fagidentitet? Veien videre? 
Sentralt i artikkelen er data fra intervjuene med elevene/lærekandidatene. Observasjoner og rapporter fra prosjektets to første år (Rokkones \& Saur, 2013, 2014) supplerer dataene fra intervjuene med elevene/lærekandidatene.

\section{Dataanalyse}

Jeg har selv transkribert intervjuene med elevene/lærekandidatene, for å få en større nærhet til materialet. Nilssen framholder at å transkribere selv er en viktig del av analyseprosessen, underveis får man ideer til koding og man blir godt kjent med materialet (Nilssen, 2012). Nilssen fremhever også at man som intervjuer kjenner konteksten og fagområdet, noe som er viktig for å oppdage nyanser i materialet. Jeg har brukt en åpen og aksial kodingsfase slik disse er beskrevet i den konstante komparative analysemetoden (Strauss \& Corbin, 1998). I analysen ble det utviklet kategorier som ble dekkende for de data som er samlet inn. Kategoriene er utviklet med utgangspunkt i spørsmålene og er som følger: skoleerfaringer, sosial tilhørighet og fellesskap, erfaringer fra bedrift. Kategoriene danner struktur for framstillingen/presentasjonen av studiens funn.

\section{Kvalitet og etikk}

Lincoln og Guba beskriver member-checking som den mest brukte metoden for å gjøre en studie troverdig (Lincoln \& Guba, 1985). For å sikre kvaliteten på intervjuene har alle deltakerne fătt tilbud om å lese transkripsjonen av sine intervju. Elevene/lærekandidatene har gitt tillatelse til å publisere deres erfaringer. Artikkelen følger prinsippet om anonymisering (Den nasjonale forskningsetiske komitè for samfunnsfag og humaniora (NESH), 2006), og ingen autentiske navn er derfor brukt. Som en del av anonymiseringen blir alle lærekandidatene beskrevet som "han", selv om ikke dette gjenspeiler informantenes variasjon når det gjelder kjønn. Skolen som har gitt tilbudet «Den tredje vei», er heller ikke oppgitt med navn i artikkelen.

Beskrivelsene og opplevelsene som er gjengitt, er knyttet til et bestemt tilbud, «Den tredje vei». Funnene som presenteres kan likevel få betydning utover denne konteksten ved at deltakernes opplevelser og tolkning av disse blir gjort kjent for andre som er opptatt av og involvert i tilsvarende tilbud for elever. Teksten representerer kunnskap og kan dermed 
fungere som et tankeredskap (Gudmundsdottir, 2001) eller tankevekker for andre som ønsker å bidra til utvikling av tilpasset opplæring i skole og bedrift med utgangspunkt i studien.

Utvalget i studien er begrenset til fire elever/lærekandidater. Selv om utvalget er lite beskriver det funn som representerer elevene/lærekandidatenes erfaringer med alternativ opplæring i forhold til muligheter, organisering, innhold, den enkeltes utvikling både faglig og sosialt. Studien gir også et eksempel på hvordan ulike instanser i opplæringen kan samarbeide for at flere elever kan oppnå en grunnkompetanse. Til tross for at funn reflekterer lokale problemstillinger og holdninger, kan studien være overførbar til liknende kontekster.

\section{Studiens funn: elevenes/lærekandidatenes erfaringer}

Studiens funn presenteres i henhold til kategoriene beskrevet under metode.

\section{Skoleerfaringer}

Denne kategorien omfatter elevenes erfaringer fra tidligere skolegang og «Den tredje vei», samt kontaktlærerens rolle En av mine informanter brukte konsekvent betegnelsen den gylne vei når han snakket om muligheten han fikk gjennom «Den tredje vei». Han fulgte «Den tredje vei» i et og et halvt år før han startet som lærekandidat i bedrift. På spørsmål om hjelp og veiledning trekker han inn kontaktlærer og prosjektleder som gode rådgivere og veiledere. Han sier:

Jeg startet på «Den tredje vei» med blanke ark. Jeg likte måten skolehverdagen var organisert på, fire dager praksis og en dag med teori. Det gikk greit med en teoridag, men jeg er en praksisperson og liker best å lære gjennom praksis. Og lærerne de var helt supre og støttet oss i tøffe tider, det var bra. Det er lenge siden, en veldig lang stund siden jeg har opplevd slik støtte.

En annen av informantene forteller at han i 2012 fikk tilbudet av prosjektleder om å starte på det han beskriver som den gylne vei. Hans tidligere erfaring var to år fra HO. Han ville bli helsefagarbeider, men ute i praksis fant han ut at det var ikke noe for ham. Da jeg spør om hvor han hadde vært hvis han ikke hadde fătt tilbudet om «Den tredje vei», svarer han: «Jeg hadde vært hjemme, dette var et viktig tilbud for meg for å snu».

En annen informant kommer fra naturbruk (NA). På grunn av mye sykdom mistet han sin skoleplass. Gjennom et samarbeid med skolen, prosjektleder og NAV fikk han tilbudet om 
«Den tredje vei». Han sier at RM var i tankene da han skulle velge programområde på videregående skole. Han beskriver at organiseringen på skolen og samarbeidet med kontaktlærer var perfekt for han.

En startet på HO, han oppdaget tidlig at dette ikke passet for han. Etter hvert fikk han tilbud om å starte på «Den tredje vei» og fikk interesse for RM. Han beskriver det som gode opplevelser da han opplevde progresjon i faget, og at han fikk mange positive tilbakemeldinger. Etter han startet som lærekandidat, har han mindre kontakt med klassen. Han savner ikke skolen, og føler at han ikke har behov for den nå. Han synes det er fint at noen av lærerne fra skolen besøker han, det gir mulighet til å diskutere fag han ønsker å ta opp. På spørsmål om hjelp og veiledning trekkes kontaktlærer og prosjektleder inn som gode rådgivere og veiledere. "Kontaktlærer har vært en tydelig leder, og det liker jeg godt," sier en i intervjuet. Han sier videre:

Han er fast og bestemt, og en glad og spøkefull person når omstendighetene tillater det. Han er også streng og bestemt hvis det er behov for det. Han liker ikke å være det, men det er bare ved behov. Han vektlegger det faglige, er seriøs og en flink fagperson som brenner for faget sitt. I den første tida på kjøkkenet var vi nybegynnere, og da så han litt mellom fingrene på det vi gjorde. Etter hvert som vi fikk erfaring ble han strengere og stilte større krav til oss, angående kvalitet.

Flere fremhever kontaktlærerens betydning, de fremhever at han veiledet dem, viste dem og oppmuntret dem til å gjøre ting på deres egen måte. De sier også at de likte at kontaktlæreren var tydelig og støttende. En sier at lærerne hadde tillit til alle som gikk i klassen, dette hadde han ikke opplevd før. Kontaktlæreren var faglig dyktig, han var flink med folk, og han blir omtalt som rettferdig. Faglig kvalitet ble vektlagt i tilbudet, det var ikke snakk om at kravene skulle senkes. Prosjektlederen fulgte opp underveis og hjalp elevene med praksisplasser. Alle fremhever ham som en viktig person for at de fikk tilbudet på «Den tredje vei».

\section{Sosial tilhørighet og fellesskap}

Det sosiale fellesskapet og vekt på tilhørighet og trygghet var sentralt $\mathrm{i}$ «Den tredje vei». Elevene som kom til gruppa, hadde opplevd nederlag i tidligere skolegang og hadde i perioder falt ut av det sosiale fellesskapet. I intervjuene beskriver de at alle som startet samtidig, hadde et godt fellesskap. Etter hvert som flere fikk kontrakter ute i bedrift, kom det inn nye elever, og da ble ikke det sosiale fellesskapet så bra. 
Opplevde at det var et godt fellesskap i gruppa inne på skolen. Etter at jeg nå er ute $\mathrm{i}$ bedrift som lærekandidat har jeg fortsatt god kontakt med en jente fra klassen, hun er min bestevenninne. Vi møtes, og meldes jevnlig.

Andre sier at etter at de ble lærekandidater har de fortsatt litt kontakt med noen fra klassen gjennom meldinger og at de møtes litt.

\section{Erfaringer fra bedrift}

Møte med bedrift for elevene i «Den tredje vei» var en ny utfordring. Som tidligere beskrevet, hadde de tett oppfølging fra skolen. Bedriftene var valgt ut fra at de ønsket denne ekstra utfordringen med å ta inn elever som på sikt kunne være aktuelle lærekandidater. For elevene dreide det seg også om at de gjennom denne utplasseringen skulle kjenne etter om det ble riktig valg av fagområde. En av informantene beskriver sine opplevelser fra første utplassering slik:

Jeg var kokk på en pub, jeg var her en måned, og var ikke fornøyd. Arbeidsoppgaver og opplæringen sviktet, jeg fikk ikke oppfølging i det hele tatt. Den eneste som hjalp meg var lærlingen i bedriften. Jeg fikk god oppfølging av kontaktlærer og prosjektleder. Med en gang de så at dette ikke gikk bra, tok de meg ut av bedriften, og jeg kom tilbake til skolen.

I intervjuene beskriver elevene erfaringer fra hvordan de ble mottatt i de ulike bedriftene. En forteller: ”Jeg ble tatt i mot med åpne armer når jeg kom til bedriften. Først var jeg nervøs, men nå er jeg ikke det. Jeg opplever at jeg er en del av teamet."

Andre startet sin praksis på skolen. En forteller at han startet sin praksis i kantina på skolen. Etter hvert ble han klar for å prøve seg ute i bedrift, og har i dag vært i samme bedriften siden mars 2014. Han er nå lærekandidat i bedriften. En annen startet som lærekandidat i august 2014 og er godt inne i bedriftens rutiner. Han går turnus som innebærer tidlige og seine vakter. Han forklarer:

Jeg har fått ansvar for desserter på kveldsvakter og forberedelse til kvelden på førstevakter, jeg hjelper til der det trengs. Jeg er blitt 20 år. Jeg samarbeider med lærlingene, det er et godt arbeidsmiljø og jeg liker opplæringen. Mitt første mål er å ta kompetansebevis, videre ønsker jeg å ta fullt fagbrev.

Han refererer også til oppfølging fra skolen som viktig i de perioder han var i bedrift før han tegnet lærekontrakt.

Yrkesvalg og elevenes/lærekandidatenes fagidentitet ble også klarer gjennom opplæringen i skole og bedrift. "Jeg hadde ikke bestemt meg, det var tilfeldig," sier en av informantene. Han var elev på en alternativ opplæring og fant seg ikke til rette. Han sier videre: 
Jeg ble ikke utfordret, jeg kom ingen vei. Jeg begynte å bli bekymret for hva jeg skulle bli, og hva jeg skulle velge videre. Så kom prosjektleder og orienterte meg om «Den tredje vei» og tilbød meg plass. Jeg fikk prøve meg både med matlaging og servering, etter hvert ble det bedrift. Etter litt prøving og feiling ble det serveringen.

Han er i dag lærekandidat innenfor servitørfaget. Han sier at han stortrives, og han understreker at han ikke har vært borte fra jobb en dag siden han startet. Kontaktlæreren har hatt veldig stor betydning for han. Han beskriver at kontaktlærer «så gleden i meg» når han fikk servere inne på skolen. "Kontaktlærer visste også at jeg var en ganske sosial type, og han rådet meg til å prøve det ut.” I intervjuene snakket vi også om yrkes- og fagidentitet. Informantene beskriver at de er på vei til å bli fagarbeidere, de opplever faglig utvikling, interessen for faget øker, og de begynner å bli fagpersoner. Alle informantene beskriver en gryende start på egen fagidentitet. Den har utviklet seg fra oppstart i skolen på «Den tredje vei» og frem til i dag. Alle uttrykker at de har utviklet seg og har fått økt interesse for fagene de har valgt.

\section{Analyse og drofting}

Tidligere skoleerfaringer har preget elevene i prosjektet. Det har vært behov for å bygge opp stillaser rundt elevene for at de skulle få positive opplevelser som grunnlag for videre utvikling, det sosiale aspektet og meningen i arbeidsoppgavene har påvirket deres læring positivt (Leave \&Wenger, 2003; Wenger, 2013). Dette ble opplevd som den gylne vei for en av mine informanter, hans beskrivelse er dekkende for alle mine informanter. Deltakerne i «Den tredje vei» fremhever god rådgiving og veiledning fra kontaktlærer og prosjektleder som viktig, samt måten tilbudet var organisert på med stort vekt på praksis. De peker på god støtte og god relasjon mellom seg selv og lærerne som viktig. Dette danner grunnlaget for god klasseledelse som fremmer læringsaktiviteter i samarbeid med elevene (Marzano, 2007; Nordahl, 2012; Ogden, 2012; Utdanningsdirektoratet, 2012).

Gjennom de årene jeg har fulgt den «Den tredje vei» har jeg sett at dette tilbudet har betydd en ny start i opplæringen der elevene tidligere har mislyktes og ikke funnet seg til rette. Tilbudet har medført mindre fravær, de liker organiseringen på skolen med vekslingen mellom skole og bedrift, praksis og teori. «Den tredje vei» har ført til at elevene fikk interesse for fagene, og de opplever progresjon i opplæringen (Wenger, 2013). God oppfølging fra 
skolen, positive tilbakemeldinger og tett kontakt med kontaktlærer som beskrives som faglig dyktig, flink med folk, rettferdig, og en tydelig leder (Nordahl, 2012; Ogden, 2012), blir nevnt. «Den tredje vei» har vist at det stilles store krav til fast og god klasseledelse, og at kontaktlærerrollen får en spesiell betydning i forhold til forutsigbarhet, trygghet og for å fremme elevenes motivasjon (Kunnskapsdepartementet, 2012).

Elevenes utvikling av sosial kompetanse er sentralt for hele grunnopplæringen og gjelder alle elever, også de i «Den tredje vei». En viktig del av deres opplæring har handlet om utvikling av sosial kompetanse, som er et viktig grunnlag for læring (Lave \& Wenger, 2003; Wenger, 2013). Opplæringen har et ansvar for at elevene får en positiv sosial utvikling og læring. Den skal legge til rette for at elevene utvikler kunnskaper, ferdigheter og holdninger som gjør dem i stand til å mestre livet og delta i sosiale fellesskap med andre (Opplæringsloven. 1998, § 9a 1,2,3; Utdanningsdirektoratet, 2006 a, b).

I opplæringen i skolen møter elevene et sosialt felleskap av jevnaldrende, og her skal de lære seg sosiale ferdigheter (Ogden, 2012). For elevene på yrkesfag vil også det sosiale fellesskapet omfatte voksne når de skal ut som lærekandidater/lærlinger i bedrift/virksomhet. Studien viser at elevene i prosjektet har et stort behov for at det jobbes mye med deres sosiale kompetanse som i neste omgang vil være avgjørende for faglig utvikling og trygge dem i samarbeid med andre elever, lærere og kollegaer ute i bedriftene. Tilbakemeldinger fra bedrifter og lærere (Rokkones \& Saur, 2013, 2014) viser at de fleste elever/lærekandidater som har fulgt «Den tredje vei», har utviklet sin sosiale kompetanse i forhold til medelever, lærere og kollegaer i bedriftene de har sin praksis. De stille har utviklet seg til kommuniserende medelever, og de har utviklet en trygghet som gjør dem i stand til å praktisere ute i bedriftene. Wenger sin vektlegging av det sosiale fellesskapet som sentralt $\mathrm{i}$ læring harmonerer godt med vektleggingen $\mathrm{i}$ «Den tredje vei» (Wenger, 2013). Elevene som kom til gruppa hadde opplevd nederlag i tidligere skolegang og hadde i perioder falt ut av det sosiale fellesskapet. I intervjuene beskriver de at alle som startet sammen, utviklet et godt fellesskap. Dette har også fortsatt etter at de startet som lærekandidater ute i bedrift. «Den tredje vei» skulle bidra til at elevene ble sikrere i sitt yrkesvalg gjennom innholdet $\mathrm{i}$ undervisningen på skolen, og etterhvert ute i bedrift. Her uttrykker flere at de var usikre i starten, men at erfaringene fra utplassering i bedrift sammen med god veiledning hjalp dem i valget. De uttrykker at de trives godt både med arbeidsoppgaver, fagområde og ikke minst alle de nye kollegaene de har fått. En uttaler at han begynner å få «lidenskap» for faget. Ifølge 
Lave \& Wenger (Lave \& Wenger, 2003) og Wenger (Wenger, 2013) vil læring som er organisert rundt et fellesskap og en praksis, som innebærer relevans og mening, vil gi mulighet for identitetsutvikling og en opplevelse av tilhørighet i et sosialt og faglig fellesskap.

Prosjektet har resultert $\mathrm{i}$ at alle elevene/lærekandidatene unngår eller har minimalt med fravær. Dette viser hvor viktig det er å gjøre riktig yrkesvalg, få veiledning og støtte underveis, bli en viktig del av et sosialt fellesskap (Lave \& Wenger, 2003; Wenger, 2013). Kontaktlæreren har hatt stor betydning i denne prosessen, en person som kjenner eleven godt og ser hva det er behov for (Nordahl, 2012; Ogden, 2012). Erfaringene elevene fikk gjennom praksis i bedrift, ble en utfordring som de taklet godt (Utdanningsdirektoratet, 2006c). Oppfølgingen fra skolen som innebar jevnlige oppfølgingsbesøk var nødvendig da det kunne være behov for justeringer, og i noen tilfelle bytte av bedrift. For mange var det også en trygghet at de kunne de komme tilbake til skolen hvis de ikke fant seg til rette i bedriften. Skolen jobbet tett med bedriftene for å få til tilpasset opplæring for den enkelte.

De valgte bedriftene var også potensielle lærekandidatbedrifter. I denne prosessen var også skoleeier og aktuelle opplæringskontor viktige støttespillere. Utsagn fra informantene beskriver de erfaringene de hadde i forbindelse med utplassering i bedrift. Intervjuene viser at elevene/lærekandidatene er godt integrert i bedriftene, de har fătt tillit, ansvar og utfører relevante arbeidsoppgaver. Godt arbeidsmiljø fremheves, og at de samarbeider godt med ansatte og lærlinger. Målet for lærekandidatene er kompetansebevis. En av informantene sier at på sikt ønsker han fullt fagbrev. Han understreker videre at oppfølging fra skolen fortsatt er viktig. Det tar tid å bygge opp trygghet, og støtte er viktig i opplæringen ikke bare i skolen, men også i bedriften (Lave \& Wenger, 2003; Wenger, 2013). Elevene/lærekandidatene bekrefter i denne studien at de er godt i gang med å bygge opp sin fagidentitet, de beskriver faglig utvikling og identifisering med fagene. De oppsummerer i intervjuet at de føler de er på vei til å bli en fagperson og fagarbeider.

Elevene/lærekandidatene sier at interessen for fagene og oppmøte på skolen startet $\mathrm{i}$ «Den tredje vei». Elever/lærekandidater som tidligere har hatt et svært høyt fravær i skoleløpet før de startet på «Den tredje vei», møter opp hver dag (Rokkones \& Saur, 2013, 2014). Informantene beskriver en gryende start på sin fagidentitet, som har utviklet seg fra oppstart i skolen og frem til i dag. Wenger sier at en sosial teori om læring må integrere flere komponenter for å karakterisere sosial deltakelse som en prosess som omfatter læring og 
innsikt (Wenger, 2013). Elevenes/lærekandidatenes læring gjennom erfaringer og opplevelser omfatter fellesskap og tilhørighet, læring gjennom praksis, opplevelse av identitet og mening (Lave \& Wenger, 2003; Wenger, 2013).

\section{Oppsummering}

Denne studien hadde som utgangspunkt å få mer innsikt i hvordan skole og bedrift kan samarbeide og tilpasse opplæringen for elever med behov for en alternativ vei til grunnkompetanse. Studien viser at det er behov for en bedre tilpasset opplæring i videregående opplæring, samt fleksible tilbud, slik at flest mulig kan gjennomføre og oppnå en grunnkompetanse. En slik tilpasning kan være lærekandidat. Det må aksepteres at ikke alle elever som starter i videregående opplæring er klare for et løp som skal ende med studie- eller yrkeskompetanse 3-5 år senere.

Rokkones og Saur oppsummerer i sin rapportering om «Den tredje vei» at det er behov for et forutsigbart tilbud som strekker seg 4-5 år. De anbefaler at prosjektet må sikres den fleksibiliteten som ligger i alle ledd (Rokkones og Saur, 2013, 2014). Dette er antakelig prosjektets viktigste suksesskriterium. Videre fremhever de en stabil prosjektledelse, her bidrar kontaktlærer og prosjektleder til robusthet $\mathrm{i}$ «Den tredje vei». Stor vekt på praksis er også en suksessfaktor som trekkes frem sammen med skolens tette oppfølging i bedrift. Elevene opplever en meningsfull opplæringssituasjon som bidrar til at å møte på jobb er viktig. Utvær viser i sin forskning til viktigheten av mestring, interesse og relevans for å finne mening med læring. Gode praksisopplevelser og relasjoner til sentrale voksne er avgjørende for at elever skal fortsette i utdanningsløpet (Utvær, 2013). Tilpasset opplæring blir svært avgjørende for de sårbare elevene som trenger svært mye støtte for å stå løpet ut. Forankring i skolens ledelse, i kollegiet og hos skoleeier er avgjørende, samt tett samarbeid med bedrifter og opplæringskontor. Det er et godt utviklingstrekk i prosjektet at flere av elevene nærmer seg målet om å tegne lærekandidatkontrakt.

Avslutningsvis vil jeg si at å ha fulgt dette prosjektet har gitt meg «gylne» øyeblikk. Jeg ser i større grad muligheter og behov for tilpasset opplæring for alle. Alternative opplæringsløp som «Den tredje vei» er et godt eksempel på hvordan skole og bedrift kan samarbeide om opplæring slik at flere ungdommer får mulighet til å få en grunnkompetanse. Dette vil gi dem 
større mulighet for å få en jobb, som i den store sammenheng er et viktig samfunnsøkonomisk anliggende.

\section{Litteratur}

Den nasjonale forskningsetiske komitè for samfunnsfag og humaniora (NESH). (2006).

Forskningsetiske retningslinjer for samfunnsvitenskap, jus og humaniora: Oslo: Den nasjonale forkningsetiske komitè for samfunnsfag og humaniora. Lastet ned 18.august 2012. http://www.etikkom.no/no/Forskningsetikk/Etiskeretningslinjer/Samfunnsvitenskap-jus-og-humaniora/

Dukes, S. (1984). Phenomenological methodology in the human sciences Journal of Religion and Health, 23(3), 197-203

Garbarino, J. (1985). Adolescent Development, An Ecological Perspective. Columbus: Charles E. Merill Publishing Company.

Gudmundsdottir, S. (2001). Narrative Research in School Practice. I V. Richardson (red.) Fourth Handbook for Research on Teaching, (s. 226-240). New York: Macmillan.

Hernes; G. (2010). Gull av gråstein. Tiltak for å redusere frafall i videregående opplaring Fafo-rapport 2010:3.

Høst, H. (2011). Disse ungdommene hadde nok ikke fullført. Evaluering av forsøk med praksisbrev. Delrapport 2. Oslo: NIFU.

Høst, H. (2013). Kvalitet i fag- og yrkesopplaeringen. Fokus på skoleopplaringen. Rapport 2. Oslo: NIFU.

Illeris, K. (2012). Loering. Oslo: Gyldendal Akademiske.

Kunnskapsdepartementet (2012). Strategi for ungdomstrinnet- Motivasjon og mestring for bedre læring. Felles satsing på klasseledelse, regning, lesing og skriving. Oslo: Departementet.

Meld. St. 20 (2012-2013). (2012). På rett vei, kvalitet og mangfold i fellesskolen. Oslo: Kunnskapsdepartementet.

Lave, J. \& Wenger, E. (2003). Situeret loering. København: Hans Reitzels forlag.

Lincoln, Y., Guba, E. (1985) Naturalistic Inquiry. CA.: Sage Publications, Newbury Park,

Markussen, E., Frøseth, N., Hovedhaugen, E., Wigum, M. (2012). Struktur og konjukturer: Evaluering av Kunnskapsløftet. Sluttrapport frå prosjektet «Tilbudsstruktur, gjennomføring og kompetanseoppnåelse $i$ videregående opplaering». Oslo: NIFU STEP 
Markussen, E., Lødding, B., Holen, S., (2012). De' hoer e'kke nokka for moe. Om bortvalg, gjennomføring og kompetanseoppnåelse i videregående skole i Finnmark (2010-2011). Oslo: NIFU STEP

Markussen, E., (2009). Fra dokumentert delkompetanse til kompetansebevis og praksisbrev. Oslo: Cappelen Damm Akademisk

Markussen, E., B. Lødding, N. Sandberg og N. Vibe (2006). Forskjell på folk-hva gjørskolen? Oslo: NIFU STEP.

Marzano, R. J. (2007). Classroom Management that works. Research-based strategies for every teacher. ASCD; Alexandria USA

Meld. St. 20 (2012-2013). (2013). På rett vei, kvalitet og mangfold i fellesskolen. Oslo. Kunnskapsdepartementet

Moustakas, C. (1994). Phenomenological Research Methods. Thousands Oaks: SAGE Publications.

Nilssen, V. (2012). Analyse i kvalitative studier. Den skrivende forskeren. Oslo: Universitetsforlaget AS.

Nordahl, T. (2002, 2010). Eleven som aktør. 2. utgave. Oslo: Universitetsforlaget AS.

Nordahl, T. (2012). Dette vet vi om klasseledelse. Oslo: Gyldendal Norske Forlag AS.

Ogden, T. (2004). Kvalitetsskolen. Oslo: Gyldendal Norske Forlag AS.

Ogden, T. (2009). Sosial kompetanse og problematferd i skolen. Oslo: Gyldendal Akademiske.

Ogden, T. (2012). Klasseledelse. Praksis, teori og forsking. Oslo: Gyldendal Norske Forlag AS.

Opplæringslova. (1998). Lov om grunnskolen og den vidaregåande opplceringa . Lastet ned 6. desember 2013 http://www.lovdata.no/all/nl-19980717-061.html

Postholm, M. B. (2010). Kvalitativ metode: en innføring med fokus på fenomenologi, etnografi og kasusstudier (2. utg.) Oslo: Universitetsforlaget.

Rokkones, K. (2014). «I verkstedet må vi ha stramme regler!» I Postholm, M. B. (red.), Ledelse av loering $i$ skolen (s. 118-137). Oslo: Universitetsforlaget

Rokkones, K. \& Saur, E. (2013) Strinda videregående skole - NTNU trykk: Prosjektrapport 1. «Den tredje vei».

Rokkones, K. \& Saur, E. (2014) Strinda videregående skole - NTNU trykk: Prosjektrapport 2. «Den tredje vei». 
Statistisk sentralbyrå (2013a). Gjennomstrømning i videregående opplæring, 2007-2012. Tilgjengelig fra: http://www.ssb.no/utdanning/statistikker/vgogjen/aar/2013-05-Lastet ned: 02.02.2014

Strauss, A \& Corbin, J. (1998). Basics of Qualitative Research: Techniques and Procedures for Developing Grounded Theory. Thousand Oaks, CA: Sage Publications, Inc.

Utdanningsdirektoratet (2012). Teoretisk bakgrunnsdokument for arbeid med klasseledelse på ungdomstrinnet. Lastet ned 4. april 2013. http://www.udir.no/Laringsmiljo/Bedrelaringsmiljo/Klasseledelse/

Utdanningsdirektoratet (2006a). Læreplaner for restaurant- og matfag Vg1 i Kunnskapsløftet. http://www.udir.no/k106/RMRMF1/ Lastet ned: 04.05.2015.

Utdanningsdirektoratet (2006b). Læreplaner for helse- og oppvekstfag i Kunnskapsløftet. http://www.udir.no/k106/HSHSF1/ Lastet ned: 04.05.2015.

Utdanningsdirektoratet (2006c). Prinsipper for opplæringen. Lastet ned 22. Des. 2017. https://www.udir.no/laring-og-trivsel/lareplanverket/prinsipper-for-opplaringen2/

Utvær, B. K. (2013). Staying in or dropping out? A Study of Factors and Critical Incidents of Importance for Health and Social Care Students in Upper Secondary School in Norway. Doktoravhandling. Trondheim: NTNU trykk.

Wenger, E. (2013). Praksisfeellesskaber. København: Hans Reitzels forlag

\footnotetext{
${ }^{\text {i }}$ En lærekandidat går i lære i bedrift for å få kompetansebevis i et yrkesfag. En grunnkompetanse for elever som kan bygges videre til yrkeskompetanse; en yrkespraksis med sikte på avgrenset eksamensbevis. Deler av et lærefag er målet, og de går opp til prøve på en individuell opplæringskontrakt.
} 